\title{
FAKTOR-FAKTOR YANG MEMPENGARUHI KINERJA COMPLAINT HANDLING OFFICER (CHO) DI UNIT KERJA CALL CENTER TELKOMSEL MAKASSAR
}

\section{FACTORS THAT INFLUENCE THE PERFORMANCE OF COMPLAINT HANDLING OFFICER (CHO) IN THE WORKING UNIT CALL CENTER TELKOMSEL MAKASSAR}

\author{
Usman Tamrin $^{1}$, Halim ${ }^{2}$ dan Syarif Ahmad ${ }^{3}$ \\ ${ }^{1}$ Call Center Telkomsel Makassar \\ e-mail: usmangolrock@yahoo.com \\ ${ }^{2}$ Sekolah Tinggi Ilmu Administrasi Lembaga Administrasi Negara Makassar \\ e-mail : halim.recht@gmail.com \\ ${ }^{3}$ Sekolah Tinggi Ilmu Administrasi Lembaga Administrasi Negara Makassar \\ e-mail : syarif_ahmad57@yahoo.com
}

\begin{abstract}
Abstrak
Petugas Complaint Handling Officer (CHO) harus memiliki kinerja sesuai Key Performance Indicator (KPI) yang telah ditetapkan oleh perusahaan dan sampai saat ini CHO Call Center Telkomsel Makassar bisa berhasil mencapai target - target yang telah ditetapkan tersebut. Adapun tujuan dari penelitian ini adalah untuk mengetahui Faktor-faktor yang mempengaruhi Kinerja Complaint Handling Officer pada Unit kerja Call Center Telkomsel Makassar. Metode penelitian yang digunakan adalah metode kuantitatif assosiatif, metode ini digunakan untuk menguji ada tidaknya pengaruh dari personal factor, leadership factor, team factor, system factor, contextual/situasional factor terhadap kinerja complaint handling officer pada unit kerja Call Center Telkomsel Makassar. Metode analisis data penelitian ini menggunakan uji normalitas, analisis regresi, dan uji hipotesis dengan bantuan SPSS versi 21. Hasil penelitian secara parsial, hubungan faktor personal tidak memiliki pengaruh positif dan signifikan terhadap kinerja $\mathrm{CHO}$ dengan nilai probabilitasnya yaitu 0,592. Faktor kepemimpinan tidak berpengaruh positif dan signifikan terhadap kinerja $\mathrm{CHO}$ dengan nilai probabilitas yaitu 0,910. ada pengaruh positif dan signifikan dari faktor team terhadap kinerja CHO dengan nilai probabilitasnya yaitu 0,014 . Faktor sistem tidak berpengaruh positif dan signifikan terhadap kinerja dengan nilai probabilitasnya yaitu 0,650 . Tidak ada pengaruh positif dan signifikan dari faktor lingkungan terhadap kinerja CHO dengan nilai probabilitasnya yaitu 0,878 . Secara simultan (uji F) semua variabel bebas yaitu personal, leadership, team, system, kontextual/situasional tidak berpengaruh dan signifikan terhadap kinerja CHO, dengan nilai probabiltas (sign) 0,052. Dapat dikatakan bahwa faktor personal, leadership, team system dan contextual/situasional secara bersama - sama tidak berpengaruh terhadap kinerja CHO.
\end{abstract}

Kata Kunci: Kinerja, Complaint Handling Officer, Personal, Leadership, Team, System, Contextual/situasional, Call Center. 


\begin{abstract}
Complaint Handling Officer (CHO) must perform according to the Key Performance Indicator (KPI) set by the company and to this day the Telkomsel Makassar Call Center CHO can successfully achieve the set targets. The purpose of this study is to determine the factors that influence the performance of the Complaint Handling Officer in the Telkomsel Call Center work unit. The research method used is quantitative associative method. This method is used to test whether there is influence fromPersonal Factor, Leadership Factor, Team Factor, System Factor, Contextual / Situational Factor to Performance Complaint Handling Officer at Call Center Unit Telkomsel Makassar. Methods of data analysis of this study are applying normality test, regression analysis, and hypothesis test with the help of SPSS version 21. Partial research results, the relationship of personal factors have no positive and significant effect on the performance of $\mathrm{CHO}$ with probability value is 0.592 . leadership factors do not have a positive and significant effect on the performance of $\mathrm{CHO}$ with a probability value of 0.910. there is a positive and significant influence of team factor on CHO performance with probability value is 0,014. system factor has no positive and significant effect on performance with probability value that is 0,650. there is no positive and significant influence of environmental factor on $\mathrm{CHO}$ performance with probability value is 0,878 . Simultaneously $(F$ test) all independent variables are personal, leadership, team, system, contextual / situational no significant and significant to CHO performance, with probabiltas value (sign) 0.052. It can be said that personal, leadership, team, system and contextual / situational factors together do not affect CHO performance.
\end{abstract}

Keywords: Performance, Complaint Handling Officer, Personal, Leadership, Team, System, Contextual/situasional, Call Center

\section{PENDAHULUAN}

Banyaknya komplain dari konsumen membuat Telkomsel membentuk sebuah wadah atau tempat untuk para konsumen tersebut untuk bisa komplain lansung, salah satunya melalui call center telkomsel 188 telkomsel. Salah satu Unit kerja yang dimili-ki oleh Telkomsel adalah Call Center Area Makassar yang melakukan back up khususnya wilayah papua, Maluku dan Sulawesi serta Kalimantan, di dalam Unit kerja ini terdapat sebuah divisi yang disebut $\mathrm{CHO}$ atau biasa disebut Complaint Handling Officer. Complaint Handling Officer melakukan atau memecahkan masalah pelanggan yang sebelumnya dibuatkan laporan tertulis oleh Operator atau agent call center yang menerima laporan via telpon dari pelanggan telkomsel area PAMASUKA (Papua Maluku Sulawesi Kalimantan), Operator yang tidak bisa menangani komplain maupun permintaan dari pelanggan tersebut akan membuat sebuah data tertulis berupa laporan yang bisa disebut "Tiket". Tiket inilah yang nantinya akan dikerjakan atau diselesaikan oleh divisi Complaint Handling Officer.

Jumlah komplain yang terus meningkat setiap harinya, maka beban kerja $\mathrm{CHO}$ juga semakin tinggi, yang dulunya bisa mengerjakan tiket dengan jumlah rata rata 25-35 komplain sehari, sekarang malah 
bertambah menjadi $40-45$ tiket per orang dalam satu hari, dan ini harus di kerjakan ataupun dibantu tindak lanjuti dalam waktu sesuai kelas tiket tersebut. Ada yang harus ditangani dalam 2 jam, 4 jam, 1x24 jam dan paling tinggi $3 \times 24$ jam. Biasanya di sebut SLA tiket (Standar Level Agreement). Belum lagi jika case yang di bantu eskalasi ke pihak Network area, maupun ke IT area. Biasanya akan memerlukan waktu yg lama.

Untuk mengukur kinerja Complaint Handling Officer, ada namanya KPI atau biasa disebut (Key Performance Indicator). Untuk parameternya sendiri yang pertama adalah Resource Quality dengan target $100 \%$, service Performance dengan target 95\%, Service Quality untuk ticket Closing target 100\% dan call back pelanggan priority target $100 \%$.

Penilaian tersebut sebenarnya sudah dilakukan setiap bulannya, dan saat ini CHO Call Center Telkomsel Makassar bisa berhasil mencapai target - target yang telah ditetapkan tersebut. Tujuan dari penelitian ini adalah untuk mengetahui faktor-faktor yang mempengaruhi Kinerja Complaint Handling Officer pada Unit kerja Call Center Telkomsel Makassar.

\section{METODE PENELITIAN}

Metode penelitian yang digunakan adalah metode kuantitatif assosiatif. Ana- lisis data pada penelitian ini menggunakan analisis statistik. Teknik pengumpulan data melalui penyebaran kuesioner, melakukan wawancara terstruktur, melakukan pengamatan serta melakukan telaah dokumen. Populasi dalam penelitian ini adalah seluruh karyawan atau petugas yang berada di divisi $\mathrm{CHO}$ yang berjumlah 30 orang. Penentuan sampel dalam penelitian ini dengan metode sampling jenuh, yang berarti keseluruhan populasi dijadikan sampling sebanyak 30 orang.

Selanjutnya untuk menentukan pengaruh dan tingkat signifikan $\mathrm{a}=0,05$ atau 5\% diuji dengan menggunakan uji-F dan uji-t melalui program komputer IBM Statistical product Service Solution (SPSS) versi 21.

1) Uji F (Fisher) yang digunakan untuk menguji apakah variabel independent/faktor yang terbentuk secara bersama - sama (simultan) berpengaruh terhadap variabel dependent (Y dengan tingkat kepercayaan (level of confidence) sebesar 95\% dengan alpha 5\%.

2) Uji-t yang digunakan untuk membuat kesimpulan mengenai pengaruh dari masing - masing variabel $(\mathrm{X})$ terhadap variabel dependen $(\mathrm{Y})$ dengan tingkat kepercayaan sebesar 95\% dengan alpha $5 \%$. 
Selain itu, data dengan skala interval (bersifat kuantitatif/parametrik), maka analisa yang digunakan adalah Pearson Correlation. Angka korelasi yang diperoleh dari hasil olah SPSS akan diinterpretasikan dengan kriteria sebagai berikut :

a) $0-0,25$ korelasi sangat lemah.

b) > 0,25-0,5 korelasi cukup baik.

c) $>0,5-0,75$ korelasi kuat.

d) $>0,75-1$ korelasi ssangat kuat.

Hubungan (korelasi), maka secara statistik dapat dinyatakan:

H0 : tidak ada korelasi antara dua variabel.

H1: ada korelasi antara dua variabel.

\section{HASIL PENELITIAN}

1) Uji Validitas

Uji validitas digunakan untuk mengukur sah atau valid tidaknya suatu kuisioner. Berdasarkan Tabel 1 diketahui bahwa semua item pertanyaan memiliki nilain sign dibawah 0,05 , sehingga itemitem pertanyaan yang mengukur variabel penelitian dinyatakan valid.

TABEL 1 Hasil Uji Validitas

\begin{tabular}{|l|l|l|l|}
\hline \multirow{2}{*}{ Variabel } & $\begin{array}{c}\text { Indi- } \\
\text { kator }\end{array}$ & $\begin{array}{c}\text { Corret- } \\
\text { ted Item } \\
- \\
\text { Total } \\
\text { Correla- } \\
\text { tion }\end{array}$ & \multicolumn{1}{|c|}{$\begin{array}{l}\text { Ket- } \\
\text { erangan }\end{array}$} \\
\hline \multirow{2}{*}{$\begin{array}{l}\text { Kinerja } \\
(Y)\end{array}$} & Kin1 & 0.000 & Valid \\
\cline { 2 - 4 } & Kin2 & 0.000 & Valid \\
\cline { 2 - 4 } & Kin3 & 0.000 & Valid \\
\hline
\end{tabular}

\begin{tabular}{|c|c|c|c|}
\hline & Kin4 & 0.000 & Valid \\
\hline \multirow{4}{*}{$\begin{array}{l}\text { Personal } \\
(\mathrm{X} 1)\end{array}$} & Per1 & 0.000 & Valid \\
\hline & Per2 & 0.002 & Valid \\
\hline & Per3 & 0.000 & Valid \\
\hline & Per4 & 0.000 & Valid \\
\hline \multirow{4}{*}{$\begin{array}{l}\text { Leader- } \\
\text { ship (X2) }\end{array}$} & Lead1 & 0.000 & Valid \\
\hline & Lead2 & 0.000 & Valid \\
\hline & Lead3 & 0.000 & Valid \\
\hline & Lead4 & 0.000 & Valid \\
\hline \multirow{4}{*}{$\begin{array}{l}\text { Team } \\
\text { (X3) }\end{array}$} & Team1 & 0.000 & Valid \\
\hline & Team2 & 0.000 & Valid \\
\hline & Team3 & 0.000 & Valid \\
\hline & Team4 & 0.000 & Valid \\
\hline \multirow{4}{*}{$\begin{array}{l}\text { System } \\
\text { (X4) }\end{array}$} & Syst1 & 0.000 & Valid \\
\hline & Syst2 & 0.030 & Valid \\
\hline & Syst3 & 0.006 & Valid \\
\hline & Syst4 & 0.000 & Valid \\
\hline \multirow{4}{*}{$\begin{array}{l}\text { Contex- } \\
\text { tual (X5) }\end{array}$} & Con1 & 0.000 & Valid \\
\hline & Con 2 & 0.000 & Valid \\
\hline & Con 3 & 0.001 & Valid \\
\hline & Con4 & 0.000 & Valid \\
\hline
\end{tabular}

Sumber : Hasil Pengolahan data 30 Responden dengan SPSS 21

2) Uji Asumsi dan Normalitas

Untuk uji normalitas, pendeteksian normalitas residual dilakukan dengan melihat digarma hstogram. Hasil uji normalitas dapat dilihat pada gambar 1 dibawah ini

GAMBAR 1 Histogram Uji Normalitas

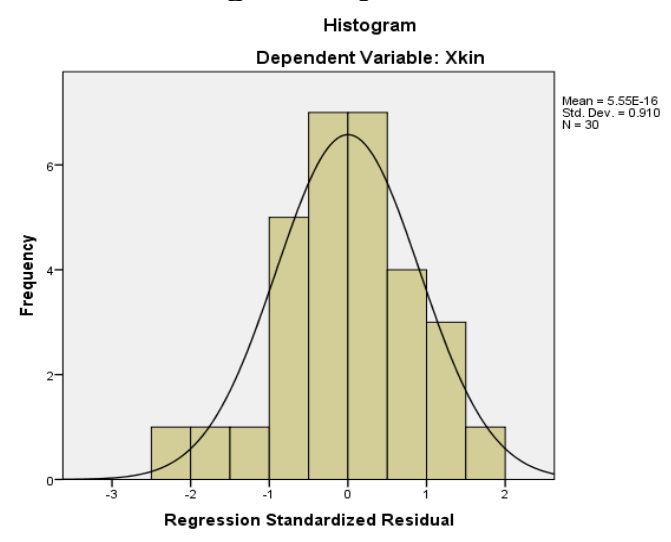


Berdasarkan gambar diatas sudah menunjukkan data tersebar membentuk genta (lonceng) sehingga dapat disimpulkan bahwa data sudah terdistribusi normal.

Untuk uji linieritas, pendeteksian linieritas dilakukan dengan normal probability plot. Jika titik-titik terkumpul di sekitar garis lurus, maka disimpulkan residual model regresi berdistribusi normal.

\section{GAMBAR 2}

\section{Hasil Uji Linieritas}

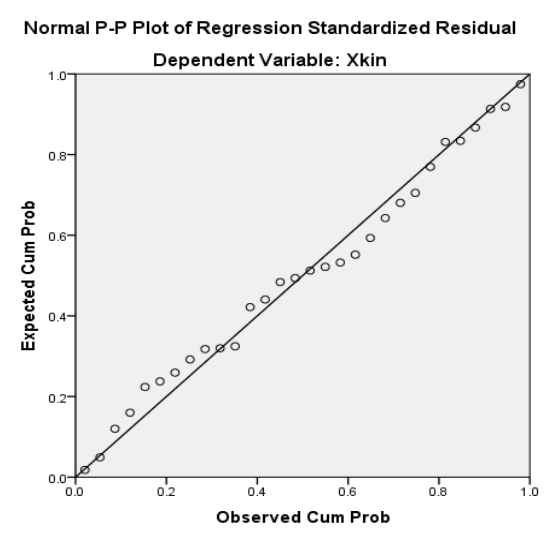

Suatu model regresi yang baik mensyaratkan tidak adanya masalah autokorelasi. Dampak yang diakibatkan dengan adanya auto korelasi yaitu varian sampel tidak dapat menggambarkan varian populasinya. Untuk mendeteksi ada tidaknya autokorelasi dapat melihat nilai DW (Durbin Watson). Apabila nilai D-W berada di antara 1,54 dan 2,46 maka tidak ada autokorelasi, dan bila nilai D-W ada diantara 0 hingga 1,10 , data mengandung autokorelasi positif. Hasil autokorelasi penelitian ini dapat nilai D-W 2,069.
Artinya tidak terjadi auto korelasi. Untuk uji heteroskedatisitas, pendeteksian ada tidaknya heteroskedastisitas dilakukan dengan scatter plot antara nilai ZPRED dan SRESID. Hasil uji heroskedastisitas dengan scatter plot. Jika titik menyebar dengan pola yang tidak jelas di atas dan dibawah angka 0 pada sumbu Y maka tidak terjadi masalah heteroskedastisitas.

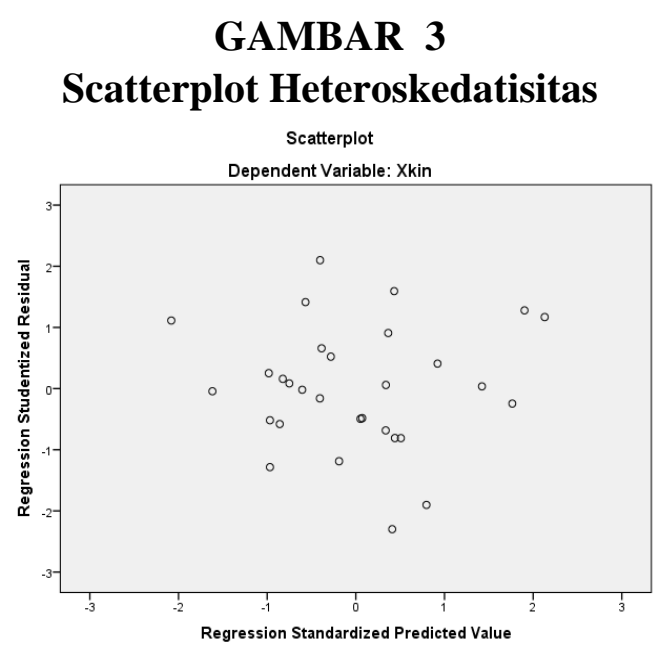

Diagram pencar diatas, bisa kita lihat jika pola yang terbentuk tidak membentuk suatu pola yang teratur sehingga disimpulkan tidak adanya masalah Heteroskedatisitas pada model regresi ini.

3) Analisis Korelai antara Variabel

Pengujian analisis korelasi antara variabel bebas denagn variabel terikat dapat dilihat dengan nilai pearson correlation. Hasil analisis korelasi didapatka dengan bantuan program SPSS 21. Rangkuman hasil analisis dapat dilihat pada tabel 2 dibawah ini. 
TABEL 2

Hasil Pengujian Autokorelasi

\begin{tabular}{|c|c|c|}
\hline \multicolumn{2}{|c|}{ Path } & $\begin{array}{c}\text { Pearson } \\
\text { Correlation }\end{array}$ \\
\hline Personal $\left(\mathrm{X}_{1}\right)$ & \multirow{5}{*}{$\begin{array}{c}\text { Kinerja } \\
\mathrm{CHO} \\
(\mathrm{Y})\end{array}$} & 0.102 \\
\hline Leadership $\left(\mathrm{X}_{2}\right)$ & & 0.022 \\
\hline Team $\left(\mathrm{X}_{3}\right)$ & & 0.443 \\
\hline System (X4) & & 0.086 \\
\hline Contextual (X5) & & 0.029 \\
\hline
\end{tabular}

Sumber : Hasil Pengolahan data 30 Responden dengan SPSS 21

Dari data tersebut menunjukkan nilai korelasi terkuat dari variabel bebas yaitu Team $\left(\mathrm{X}_{3}\right)$ dengan Pearson Correlation sebesar 0,443 terhadap kinerja karyawan.

4) Hasil pengujian hipotesis

Melakukan hasil analisis penelitian, yaitu melakukan penafsiran terhadap pengujian hipotesis. Walaupun hasil analisis statistik itu sendiri sudah merupakan suatu kesimpulan, tetapi belum memadai tanpa ada yang dikaitkan dengan perumusan masalah. Pengujian hipotesis dalam penelitian ini dilakukan dengan melihat nilai probabilitas (signifakan).

Berdasarkan hasil rangkuman tabel 3 dapat disimpulkan bahwa hipotesis dari penelitian variabel bebas (Personal, Leadership, System dan Contextual) tidak berpengruh signifikan terhadap variabel terikat (kinerja $\mathrm{CHO}$ ). Sedangkan variabel
Team berpengruh signifikan terhadap variabel terikat (kinerja $\mathrm{CHO}$ ).

TABEL 3

\section{Hasil Pengujian Hipotesis Secara Parsial}

\begin{tabular}{|l|l|}
\hline Hipotesis & Sign \\
\hline Personal $\left(\mathrm{X}_{1}\right)$ & 0,592 \\
\hline Leadership $\left(\mathrm{X}_{2}\right)$ & 0,910 \\
\hline Team $\left(\mathrm{X}_{3}\right)$ & 0,014 \\
\hline System $(\mathrm{X} 4)$ & 0,650 \\
\hline Contextual (X5) & 0,878 \\
\hline
\end{tabular}

Sumber : Hasil Pengolahan data 30 Responden dengan SPSS 21

Dari tabel 4 , dapat dilihat nilai $\mathrm{F}$ adalah dengan probabilitas 0,052>0,05. Maka model regresi dapat dikatakan bahwa faktor personal, leadership, team, system dan contextual/situasional secara bersama - sama tidak berpengaruh terhadap kinerja $\mathrm{CHO}$.

TABEL 4

\section{Hasil Pengujian Hipotesis} Secara Simultan

\begin{tabular}{|l|l|}
\hline Predictors (Contant) & Sign \\
\hline $\begin{array}{l}\text { XCon, XLead, XSyst, XPer, } \\
\text { XTeam }\end{array}$ & 0,052 \\
\hline $\begin{array}{l}\text { Sumber : Hasil Pengolahan data } 30 \text { Respond- } \\
\text { en dengan SPSS } 21\end{array}$
\end{tabular}

\section{PEMBAHASAN}

\section{Hipotesis 1}

Berdasarkan hasil pengujian hipotesis secara parsial antara hubungan personal faktor terhadap kinerja $\mathrm{CHO}$ 
menunjukkan nilai probabilitasnya yaitu 0,592, karena nilai probabilitas jauh diatas 0,05 . Maka hipotesisnya H0 diterima (H1 ditolak). Jadi bisa dikatakan jika faktor personal tidak memiliki pengaruh positif dan signifikan terhadap kinerja CHO di Call Center Telkomsel Makassar. Hal ini memungkinkan terjadi karena petugas $\mathrm{CHO}$ sudah memiliki skill yang bagus dalam menangani komplain pelanggan, dikarenakan petugas $\mathrm{CHO}$ adalah dulunya seorang caroline officer atau operator layanan, sehingga saat ini, setelah berpinda ke divisi $\mathrm{CHO}$, itu mempermudah pekerjaannya seperti pencarian sumber data yang bisa dan pengecekan sehingga mampu memberikan jawaban yang sesuai dengan komplain dari pelanggan.

Hasil dari penelitian ini mendukung hasil dari penetian terdahulu dari (Almilia, Briliantien , 2007) yaitu Kemampuan personal, tidak berpengaruh terhadap kepuasan dan kinerja Sistem Informasi Akuntansi Pada Bank Umum Pemerintah di Wilayah Surabaya dan Sidoarjo. Selain itu ada juga penelitian terdahulu dari (Suwati, 2013) yaitu variabel motivasi kerja secara parsial tidak berpengaruh positif dan signifikan terhadap kinerja karyawan pada PT. Tunas Hijau Samarinda. Secara teori, hal ini tidak sejalan dengan apa yang diungkapkan oleh Amstrong dan Baron (Wibowo ,2009) yang mendefinisikan bahwa personal factor ditunjukkan oleh tingkat keterampilan, kompetensi yang dimiliki dan komitmen individu. Selain itu pendapat lain dari Hasibuan (2009) mengatakan jika manusia selalu berperan aktif dan dominan dalam setiap kegiatan organisasi, karena manusia menjadi perencana, pelaku, dan penentu terwujudnya tujuan organisasi. Tujuan tidak mungkin terwujud tampa peran aktif karyawan meskipun alat alat yang dimiliki perusahaan begitu canggihnya.

\section{Hipotesis 2}

Berdasarkan hasil analisis pada bab sebelumnya menyatakan bahwa hasil pengujian hipotesis ini telah membuktikan bahwa faktor kepemimpinan tidak berpengaruh positif dan signifikan terhadap kinerja CHO Call center Telkomsel makassar. Melaui pengolahan data melalui SPSS didapatkan nilai probabilitas yaitu 0,910 lebih besar dari 0,05. dan t-hitung sebesar 0.115, maka H0 diterima (H1 ditolak). Hal ini memungkinkan terjadi karena beberapa atasan seperti Team Leader yang ada, tidak ikut mengambil peran dalam mengerjakan tiket. Dan di divisi $\mathrm{CHO}$ sendiri tugas dari pimpinan seperti team leader maupun Supervisor, hanya menjalankan tugasnya sesuai dengan fungsi serta melakukan monitoring terhadap pekerjaan yang dilakukan oleh peugas $\mathrm{CHO}$. 
Hasil penelitian ini konsisten dan mendukung penelitian terdahulu dari (Hasbidin, 2017) yaitu faktor kepemimpinan hasil pengolahan data ditemukan bahwa tidak adanya pengaruh yang signifikan terhadap kinerja pegawai Bank Syariah Mandiri di kota Medan. Selain itu menguatkan juga penelitian terdahulu dari (Fauza dan Wismantoro, 2014) yang memiliki hasil penelitian variabel kepemimpinan memiliki pengaruh yang lemah dalam mempengaruhi kepuasan kerja maupun kinerja Kinerja Pegawai Negeri Sipil Pada Badan Pertanahan Nasional Kabupaten Boyolali. Selain kedua penelitian tersebut, penelitian ini juga mendukung penelitian terdahulu dari (Marpaung, 2014) yaitu secara parsial kepemimpinan berpengaruh tidak signifikan terhadap Performans Pegawai Koperasi di Sekjen Kemdidbud Senayan Jakarta. Hal ini tidak sejalan dengan teori yang dikemukakan oleh Amstrong dan Baron (Wibowo, 2009) yang mengatakan bahwa Leadership factor, ditentukan oleh kualitas dorongan, bimbingan dan dukungan yang dilakukan manager atau team leader. Pendapat lain yang dikemukakan oleh (Usman, 2008) menjelaskan tentang Manusia sebagai pemimpin dari suatu organisasi harus mampu mengarahkan dan membimbing bawahannya dalam melaksanakan aktivitas organisasi.
Jika melihat hasil dari penelitian ini dan penelitian terdahulu serta membandingkannya dengan teori yang ada, maka bisa dikatakan memang mungkin dalam melaksanakan tugasnya, petugas CHO mampu menyelesaikan pekerjaannya tepat waktu dan sesuai dengan standar kerja yang ada di call center telkomsel Makassar. Tanpa harus mendapatkan bimbingan lansung dari para atasan seperti team leader, karena secara tidak lansung petugas $\mathrm{CHO}$ sudah paham dan mengerti dengan apa yang dikerjakannya karena pengalaman yang mereka dapatkan senddiri, maupun dari rekan kerjanya lansung sesama petugas $\mathrm{CHO}$.

\section{Hipotesis 3}

Berdasarkan hasil pengujian hipotesis memperlihatkan adanya pengaruh positif dan signifikan dari faktor team terhadap kinerja $\mathrm{CHO}$ di Call center Telkomsel makassar. Hal ini dilihat perolehan nilai probabilitasnya yaitu 0,014 $<0,05$, dan t-hitung sebesar 2.614, maka H0 ditolak (H1 diterima). Artinya faktor tim berpengaruh positif dan signifikan terhadap Kinerja CHO. Kondisi tersebut dimungkinkan terjadi karena faktor tim tersebut merupakan bagian dari kerjasama dari rekan sesama $\mathrm{CHO}$, pengaruh dan hubungan baik sesama $\mathrm{CHO}$, dukungan, serta kritik dan saran dari rekan sekerja yang terkait dengan pekerjaannya sehinnga 
prestasi kerja CHO Call center Telkomsel makassar akan meningkat yang juga akan meningkatkan kinerja perusahaan.

Hasil penelitian ini mendukung dan konsisten dengan penelitian terdahulu dari (Marpaung, 2014), yaitu Terdapat pengaruh positif signifikan teamwork terhadap kinerja pegawai koperasi di Sekjen Kemdikbud Senayan Jakarta. Hal ini tentu saja sejalan dengan teori yang dikemukakan oleh Amstrong dan Baron dalam Wibowo (2009) yang mengatakan bahwa Team factor, ditunjukkan oleh kualitas dukungan yang diberikan oleh rekan sekerja. Pendapat mengenai pengaruh tim dalam kinerja dikemukakan juga oleh (Thoha, 2009) mengatakan jika manusia sebagai makhluk sosial tidak dapat hidup sendiri. Mereka mempunyai ketergantungan satu sama lain dalam memenuhi kebutuhannya untuk itu mereka membentuik kelompok.

Faktor tim menjadi kunci utama di dalam divisi $\mathrm{CHO}$, karena dalam menyelesaikan tugas dan tanggung jawab untuk menyelesaikan komplain dari pelanggan bisanya mereka saling membatu, memberikan dukungan satu sama lainnya, serta selalu menjaga kekompakan tim, sehingga ini menjadi sebuah cara yang sangat efektif dalam hal meningkatkan kinerja divisi $\mathrm{CHO}$ yang nantinya pasti meningkatkan kinerja perusahaan.

\section{Hipotesis 4}

Berdasarkan hasil pengujian hipotesis tidak memperlihatkan adanya pengaruh positif dan signifikan dari faktor Sistem terhadap kinerja CHO di Call center Telkomsel Makassar. Hal ini dilihat dari perolehan nilai probabilitasnya yaitu $0,650>0,05$, dan t-hitung sebesar 0.458, maka H0 diterima (H1 ditolak). Artinya faktor sistem tidak berpengaruh positif dan signifikan terhadap Kinerja CHO. Ini bisa saja memungkinkan terjadi karena semua petugas $\mathrm{CHO}$ sudah memiliki tanggung jawab masing masing, misalkan sistem jam kerja shifting yang diterapkan, jadi masing - masing $\mathrm{CHO}$ sudah memiliki roster masing - masing sehingga bisa dan mampu menyesuaikan diri terhadap jenis pekerjaan dan job desk yang mereka lakukan di kantor. Selain itu, petugas $\mathrm{CHO}$ juga bisa melakukan tukar dinas atau menukar jadwal shiftingnya dengan rekan sesama CHO. Ini memberikan ruang yang baik untuk tetap bisa berkinerja baik. Penelitian ini mendukung penelitian terdahulu dari (Kurniadi dan Suryadi, 2013) yaitu pengaruh yang sangat kecil dari budaya organisasi terhadap kinerja Dinas Pendidikan Provinsi jawa Barat.

Dalam sistem kerja dan budaya organisasi yang sudah ditanamkan Call Center Telkomsel Makassar, salah satunya adalah Loyalty yaitu kesetiaan dilandasi 
dengan adanya kepercayaan (faithfulness) yang berujung pada ketaatan (obey) sehingga meninggalkan komitmen komitmen secara penuh kepada perusahaan, pimpinan, norma, etika dan akal sehat. Sedangkan jika dilihat dari sudut pandang teori Amstrong dan Baron dalam Wibowo (2009) yang mengatakan bahwa System factor, ditunjukkan oleh adanya system kerja dan fasilitas yang diberikan oleh organisasi.

Pendapat lain juga dari Bacal (2001) mengemukakan bahwa Sistem adalah seperangkat komponen yang bekerja secara bersama-sama secara independen untuk mencapai sesuatu. Sistem tersebut menerima input dan melalui serangkaian proses dan mengubah input tersebut menjadi output produk, jasa ataupun informasi. Sistem kerja adalah serangkaian dari beberapa kegiatan yang berbeda kemudian dipadukan untuk menghasilkan suatu benda atau jasa yang menghasilkan nilai bagi pelanggan atau keuntungan organisasi. sistem dan prosedur kerja dalam organisasi adalah unsur dalam peningkatan tata kelola organisasi yang baik, karena keteraturan dan pelaksanaan tugas secara sistematis mempermudah capaian kinerja sesuai dengan standar yang ditetapkan.

\section{Hipotesis 5}

Berdasarkan hasil pengujian hipotesis memperlihatkan tidak adanya pengaruh positif dan signifikan dari faktor lingkungan terhadap kinerja $\mathrm{CHO}$ di Call center Telkomsel makassar. Hal ini dilihat perolehan nilai probabilitasnya yaitu 0,878 $>0,05$, dan t-hitung sebesar 0.154, maka H0 diterima (H1 ditolak). Artinya faktor lingkungan tidak berpengaruh positif dan signifikan terhadap Kinerja CHO.

Penelitian ini mendukung penelitian terdahulu dari (Dhermawan, Sudibja dan Utama, 2012) yaitu Lingkungan kerja berpengaruh tidak signifikan terhadap kepuasan kerja dan kinerja Pegawai di Lingkungan Kantor Dinas Pekerjaan Umum Provinsi Bali. berbeda dari apa yang dikatakan oleh Amstrong dan Baron dalam Wibowo (2009:99), yang mengatakan bahwa Contextual/situasional factor, ditunjukkan oleh tingginya tekanan dan perubahan lingkungan internal dan eksternal. Ada dua lingkungan yang berpengaruh terhadap organisasi, yaitu lingkungan social dan lingkungan keraja. Lingkungan sosial meliputi tekanan-tekanan umum yang mempengaruhi secara luas, misalnya tekanan di bidang ekonomi, teknologi, politik, hokum, dan sosial budaya.

Kondisi tersebut dimungkinkan terjadi karena faktor lingkungan seperti tekanan dari pimpinan, suasana organisasi yang tidak nyaman, dukungan dari pihak Network, IT dan BES. tersebut merupakan sebuah lingkungan yang dijalani oleh $\mathrm{CHO}$ 
setiap harinya yang terkait dengan pekerjaannya sehinnga hal tersebut tidak berpengaruh ke petugas $\mathrm{CHO}$ nya secara lansung.

\section{Hipotesis 6}

Secara simultan (uji F) semua variabel bebas yaitu personal, leadership, team, system, kontextual/situasional tidak berpengaruh dan signifikan terhadap kinerja $\mathrm{CHO}$, dengan nilai probabiltas (sign) 0,052. Karena probabilitas sedikit lebih besar 0,05. Maka model regresi dapat ini tidak bisa digunakan untuk memprediksi Kinerja $\mathrm{CHO}$, atau dapat dikatakan bahwa faktor personal, leadership, team, system dan contextual/situasional secara bersama - sama tidak berpengaruh terhadap kinerja CHO. Hasil dari peneltian ini berbeda atau tidak sejalan dengan penelitian terdahulu oleh (Aurelia Potu, 2013) yaitu kepemimpinan, motivasi, dan lingkungan kerja secara simultan berpengaruh positif dan signifikan terhadap kinerja karyawan pada Kantor Wilayah Ditjen Kekayaan Negara Suluttenggo Dan Maluku Utara Di Manado.

\section{KESIMPULAN}

Dengan memperhatikan hasil penelitian dan pembahasan yang telah dijelaskan, maka ditarik kesimpulan sesuai dengan perumusan masalah yaitu faktor individu tidak berpengaruh positif dan sig- nifikan terhadap kinerja $\mathrm{CHO}$ Call Center Telkomsel makassar. Faktor Kepemimpinan tidak berpengaruh positif dan signifikan terhadap kinerja $\mathrm{CHO}$ Call Center Telkomsel Makassar. Faktor Tim berpengaruh positif dan signifikan terhadap kinerja CHO Call Center Telkomsel Makassar. Faktor Sistem tidak berpengaruh positif dan signifikan terhadap kinerja CHO Call Center Telkomsel Makassar. Faktor Lingkungan/kontekstual tidak berpengaruh positif dan signifikan terhadap kinerja $\mathrm{CHO}$ Call Center Telkomsel Makassar. Secara simultan, kelima variabel bebas yaitu individu, kepemimpinan, tim, sistem dan lingkungan secara bersamaan tidak memiliki pengaruh terhadap kinerja karyawan $\mathrm{CHO}$.

Dengan pemberian pelatihan atau training soft skill, maupun hard skill sehingga bisa menambah keterampilan serta motivasi yang menunjang dalam peningkatan kinerja karyawan di divisi $\mathrm{CHO}$. Dorongan, bimbingan, dukungan serta petunjuk dan arahan dari team leader diharapkan lebih maksimal. Kekompakan tim seperti pengaruh dan hubungan baik sesama $\mathrm{CHO}$, dukungan, serta kritik dan saran dari rekan sekerja sekiranya dapat di pertahankan. Sistem kerja dan fasilitas yang diberikan oleh organisasi mungkin bisa dibenahi lagi. Lingkungan karyawan juga harus lebih diperhatikan lagi, ling- 
kungan internal termasuk suasana kantor dan lingkungan eksternal harus lebih bisa di perhatikan dalam hal penyelesaian komplain pelanggan ke IT, Network dan BES (Back End Support).

\section{REFERENSI}

Almilia, Luciana Spica dan Briliantien, Irmaya. 2007. Faktor - faktor yang mempengaruhi Kinerja Sistem Informasi Akuntansi Pada Bank Umum Pemerintah di Wilayah Surabaya dan Sidoarjo. Jurnal STIE Perbanas Surabaya (2007) [Online]

Bacal, Robert. 2001. Performance Management: Memberdayakan Karyawan, Meningkatkan Kinerja Melalui Umpan Balik, Mengukur Kinerja, Jakarta: Gramedia Pustaka.

Dhermawan, Bagus, Adyana Sudibya dan Mudiartha Utama. 2012. Pengaruh Motivasi, Lingkungan Kerja, Kompetensi, dan Kompensasi terhadap Kepuasan Kerja dan Kinerja Pegawai di Lingkungan Kantor Dinas Pekerjaan Umum Provinsi Bali. Matrik: Jurnal Manajemen, Strategi Bisnis dan Kewirausahaan. 6 (2). p 173-184 [online]

Fauza, Desi Herma dan Yohan Wismanto. 2014. Analisis Faktor-Faktor yang
Mempengaruhi Kinerja Pegawai Negeri Sipil Pada Badan Pertanahan Nasional Kabupaten Boyolali. Media. 22(1). p 72-89 [online]

Marpaung, Marudut. 2014. Pengaruh kepemimpinan dan Team work Terhadap Kinerja Karyawan Di Koperasi Sekjen Kemdikbud Senayan Jakarta. Jurnal Ilmiah WIDYA. 1(1). p 33-40 [online]

Potu, Aurelia. 2013. Kepemimpinan, Motivasi, dan Lingkungan Kerja Pengaruhnya terhadap Kinerja Karyawan pada Kanwil Ditjen Kekayaan Negara Suluttenggo dan Maluku Utara Di Manado. Jurnal EMBA: Jurnal Riset Ekonomi, Manajemen, Bisnis dan Akuntansi. 1(4) p 12081218 [online]

Suwati, Yuli. 2013. Pengaruh Kompensasi dan Motivasi Kerja terhadap Kinerja Karyawan pada PT. Tunas Hijau Samarinda. Jurnal Ilmu Administrasi Bisnis. 1(1). P 41-55 [online]

Thoha, Miftah. 2009. Perilaku Organisasi: Konsep Dasar dan Aplikasinya, Jakarta: Rajawali Pers

Usman, Husaini. 2008. Manajemen: Teori, Praktek dan Riset Pendidikan, Edisi 2. Jakarta: Bumi Aksara.

Wibowo. 2010. Managemen Kinerja, Edisi Kedua. Jakarta: Rajawali Pers. 